\title{
FIJI
}

\section{8. 'Stifled aspirations' The 2014 General Election under restrictive laws}

\begin{abstract}
On 17 September 2014, eight years after the 5 December 2006 coup, Fiji held a General Election under repressive laws curtailing freedom of expression and the media, government accountability and the judiciary. A notable number of 248 candidates aspired for the 50 parliamentary seats under the 2013 Constitution and an Electoral Decree released a few months prior to elections. In an atmosphere of lavish campaign advertisements on billboards, public transport vehicles and the print and television news media by the post-coup Prime Minister Voreqe Bainimarama's political party FijiFirst, recently activated political parties struggled to have their voices heard. Two daily media companies - the Fiji Broadcasting Corporation and the Fiji Sun - displayed bias towards the FijiFirst party by providing them with excessive and preferential coverage and portraying other parties in a negative light; other media organisations attempted to give fairer coverage. The debate heated up amid crackdowns by police on 'trouble-makers' vandalising FijiFirst posters. The country headed for the polls as celebrations marked the release of 45 Fijian soldiers held hostage by Al-Nusra in the Golan Heights. Amid complaints by five political parties, the election was declared 'free and fair' by the Electoral Commission. This article, through analysis of media materials, campaigning, polling and results calculations, contends that the elections only satisfied part of the international criteria for 'free and fair elections'.
\end{abstract}

Keywords: accountability, censorship, elections, Fiji, freedom of expression, freedom of information, media freedom

\section{MOSMI BHIM}

Fiji National University

IJI was ruled by decree by an unelected government for eight years after the 5 December 2006 coup. Coup leader and Prime Minister Commodore Voreqe Bainimarama assured citizens of holding elections after the launch of the People's Charter in 2009. Instead, the 1997 Constitution was abrogated and decrees promulgated to restrict the judiciary, freedom of expression and the media, right to freedom of assembly and association, and the work of independent bodies and civil society organisations.

108 PACIFIC JOURNALISM REVIEW 21(1) 2015 
Widespread consultations by the Constitution Commission in 2012, headed by renowned Kenyan constitutional specialist Professor Yash Ghai, renewed hopes among individuals, civil society organisations and disarrayed political parties that Fiji might return to parliamentary democracy. These hopes were dashed when the draft constitution was rejected and reportedly burned in the presence of Ghai by police in a move that shocked the region (Torching of Fiji's constitutional papers, 2013). After much speculation by the public, the regime promulgated into law its own version of the 2013 Constitution, which was released to the public by the Attorney-General Aiyaz Sayed-Khaiyum on 22 August 2013 (Constitution of Fiji, 2013) and was assented to by the President on September 62013 (Fiji Elections Office website, 2013) to pave the way for elections to be conducted by September 2014. People remained sceptical about the government's commitment to hold elections in 2014, as enabling legislation for holding elections had not been released to the public. Even before the finalised constitution was released, a Political Parties (Registration, Conduct, Funding and Disclosures) Decree was released to the public on 15 January 2013. The September 17 date for elections was announced in late March 2014 (Radio Australia, 29 March 2014) to coincide with the release of the Electoral Decree 2014 on 28 March (Fiji government, 28 March 2014).

However, instead of creating confidence, the offences and harsh penalties under these three enforced decrees had an unsettling effect on aspiring politicians. Parties appeared to have difficulty in recruiting candidates, and the majority of candidate names were only announced in the two months prior to elections. Political parties lacked confidence and did not feel secure to campaign because of the harsh penalties. No clear dates were given as to when campaigning would be allowed to start. Political parties were still waiting for the electoral office to signal the start of campaigning when there was a sudden release of lavish advertisements by the new FijiFirst party which made the other political parties realise they were allowed to campaign now.

In an atmosphere of lavish campaign advertisements on daily television, newspapers, billboards and public transport vehicles by the post-coup PM Bainimarama's political party FijiFirst, recently activated political parties struggled to have their voices heard. Two daily media companies - the Fiji Broadcasting Corporation and the Fiji Sun - displayed blatant bias towards the FijiFirst party by providing them with excessive and preferential coverage and portraying other parties in a negative light; other media organisations attempted to give fairer coverage. The debate heated up amid crackdowns by police on 'trouble-makers' vandalising FijiFirst posters (Loga, 2014a). The country headed for polls as celebrations marked the release of 45 Fijian soldiers held hostage by Al-Nusra in the Golan Heights. The election was declared 'free and fair' by the Chairman of the Electoral Commission Chen Bunn Young amid complaints by five political parties (Swami, 2014). The Multinational Observer Group (MOG) said it was a 'credible' election a day after polling (Narayan \& Turaga, 2014). This article, through analysis of media materials, campaigning, polling and results calculations, contends that the elections only satisfied 
POLITICAL JOURNALISM IN THE ASIA-PACIFIC

some of the international criteria for 'free and fair elections', as not all citizens were able to participate freely and fully in the 2014 'democratic' elections. This article will analyse the elections in two aspects: firstly, the Declaration on Criteria for Free and Fair Elections adopted by the Inter-Parliamentary Union (IPU) Council in 1994, and Fiji's new electoral and media laws.

\section{IPU criteria on free and fair elections}

The IPU reaffirms Article 21 (3) of the Universal Declaration of Human Rights (UDHR, 1948) that: '...The will of the people shall be the basis of the authority of government; this will shall be expressed in periodic and genuine elections ...' A coup-installed government does not have legitimacy to rule as the people did not provide them authority to rule through periodic genuine elections. The rule by the unelected Bainimarama regime continued to raise concerns as it violated this essential human right of citizens and made it more urgent to convene national elections.

The IPU has four sections in its Declaration on Criteria for Free and Fair Elections, which are: Free and Fair Elections; Voting and Elections Rights; Candidature, Party and Campaign Rights and Responsibilities; and the Rights and Responsibilities of States.

Section 1. Free and Fair Elections requires '...genuine, free and fair elections held at regular intervals...' According to the UN Centre for Human Rights (1994, pp. 11-12), periodic elections are necessary for '... a sustained political order, continually answerable to the will of the people.... to ensure that governmental authority continues to reflect the will of the people.' It states the interruption of periodicity will violate international standards. The 2006 coup, through removal of an elected Parliament, resulted in excessive power being held by the Bainimarama government as the electorate had no say in the policies and directions of the regime for eight continuous years; there were no elected opposition members of parliament (MPs) to scrutinise government activities and hold them accountable, thus leaving the power unchecked.

Fiji was obliged to hold elections in 2008 to satisfy the Millbrook Commonwealth Action Programme on the Harare Declaration issued by Commonwealth Heads of Government on 12 November 1995 in Millbrook, New Zealand, to protect democracy and democratic processes, where up to two years' time frame is given for the 'restoration of democracy where the institutions are not in place to permit the holding of elections within, say, a maximum of six months' (Millbrook Declaration, 1995 pp. 3-4). The interim government did not meet this obligation. After the abrogation of Fiji's 1997 Constitution on 10 April 2009, the Commonwealth fully suspended Fiji's membership when Bainimarama refused to commit by 1 September 2009, to have credible elections by October 2010 (BBC News, 2009) as he wanted to achieve his 'roadmap' before elections in 2014. The achievement of the goals in the 'roadmap' gave the Bainimarama regime an unfair advantage over the other political parties as they had a very long time to achieve the goals

110 PACIFIC JOURNALISM REVIEW 21(1) 2015 
of economic and infrastructure developments, without having to seek the approval of voters or scrutiny from parliamentarians. The 2006 coup and the postponement of general elections for eight years violated the free and fair elections criterion as an unelected government was in power, and the postponing of periodic elections meant that the voters were unable to control the power of the ruling regime.

The UN Centre for Human Rights (1994, p. 6), in its explanation of the criteria on free and fair elections, states that: 'To be free, participation in elections must be conducted in an atmosphere characterised by the absence of intimidation and the presence of a wide range of fundamental human rights. To that end, obstacles to full participation must be removed and the citizenry must be confident that no personal harm will befall them as a result of their participation' and '... laws in force which might have the effect of discouraging political participation should be repealed or suspended.' A majority of the political parties - the Social Democratic Liberal Party (SODELPA), National Federation Party (NFP), Fiji Labour Party (FLP), People's Democratic Party (PDP) and Independent candidate Roshika Deo-were forced to participate in the elections under decrees that they opposed and which were not modified or removed, even after many concerns raised by citizens and civil society organisations (CSOs) in submissions to international bodies and media releases.

\section{Section 2: Voting and elections rights}

The registration, polling and vote-counting processes of Fiji's 2014 general elections largely satisfied six of the seven clauses in the IPU Declaration's Section 2. Voting and Elections Rights as there was no discrimination in citizens' right to vote; there was a non-discriminatory procedure for the registration of voters; there were very few cases of eligible citizens who were denied the right to vote or disqualified from registration voters had reasonable access to polling stations; voters had equal rights to vote and their votes had equal value; and the secrecy of the vote was reasonably met apart from visuallyimpaired, sick or elderly voters who required assistance to vote. Only clause (4) of the second criterion was not satisfied, as reasonable provision was not made to cater for appeals by the few individuals who were denied the right to vote or be registered as voters. This article now examines the remaining two criteria and the clauses which were not satisfied by the conduct of the 2014 elections.

\section{Section 3. Candidature, party and campaign rights and responsibilities}

Clause (1) 'Everyone has the right to take part in the government of their country and shall have an equal opportunity to become a candidate for election.'

Fiji's unstable political history after independence has seen four coups in 44 years

of independence. The 'Fiji the way the world should be' bliss was only enjoyed for 16 years after Independence. The rest of the 28 years has been spent in the shadow of the 
POLITICAL JOURNALISM IN THE ASIA-PACIFIC

simmering threat of a takeover by the country's military, which grew in size and strength after the deployment of the first peacekeeping mission to Lebanon in 1978. According to Baledrokadroka (2012, p. 106) 'Since its first peacekeeping deployment in 1978, the military's peacekeeping role has been controversial, as it has unintentionally aided political instability in Fiji.' The 2006 coup led to further militarisation of the civil service as well as key statutory bodies (see Bhim, 2011).

Bainimarama stated that he became PM after the coup to ensure the success of his 'clean-up campaign' against government corruption, and that he would not contest the election (SMH, 2007). However, in March 2012, Bainimarama announced he was considering standing in the elections (RNZI, 2012). To pave the way to contest the elections, Bainimarama announced Colonel Mosese Tikoitoga to be the new army commander in March 2014 (Vukailagi, 2014) and his own title reverted to Rear Admiral Bainimarama. Comments by the new military commander, Brigadier General Tikoitoga, that political parties should 'leave the military alone and it should not be part of their campaign' and that their role is to protect the 2013 Constitution (Susu, 2014) which entrenches immunity for the 2006 coup makers, interfered with campaigns as it bred fear among aspiring political party candidates, as well as the general public. The military is a political actor in Fiji and it has historically been shown that the military in Fiji is not apolitical, but tends to be biased towards a particular party. Tikoitoga's numerous statements that the military will protect the 2013 Constitution (on the eve of elections, during the blackout period) was intimidating because many political parties had pledged in their election manifestos to change problematic aspects of the Constitution. The implication was that the military may take adverse action if the winning party attempted to change the constitution.

Bainimarama, in his first interview on 4theRecord programme on FBC TV, (Ep 36, 2014) assured interviewers Edwin, Peceli and Nemani that ' ...there will never be a repeat of the (political) events of 2000 and 2006. The 2006 was the end of all coups that's why we came up with the clean-up campaign .... And if you follow the 2013 Constitution there will be no coups'. Of particular concern to individuals and CSOs was the continuous link Bainimarama and Tikoitoga made between the entrenchment of the 2013 Constitution and prevention of future coups, as no statements or assurances were provided on what action Bainimarama or the Republic of Fiji Military Forces (RFMF) might take if attempts were made to change the 2013 Constitution or court action was taken to have it declared illegal - an action that was proposed in the manifestos of several political parties. A week prior to the 2014 Elections, Bainimarama stated on FBC News that 'Suva will not be allowed to burn as it did in 2000' and the full brunt of the law and security forces would be imposed on anybody who caused trouble (Stolz, 2014). The PM also led a thanksgiving ceremony for the Golan-released soldiers at $4 \mathrm{pm}$ next to the elections results venue, less than 24 hours before the commencement of elections the following day at 7.30am on September 17.

112 PACIFIC JOURNALISM REVIEW 21(1) 2015 
These statements had several effects-firstly, they created fear among Indo-Fijian voters that if the SODELPA party won, they could be terrorised and victimised again as in the aftermath of the 2000 coup; secondly, it intimidated supporters of the other political parties that the military could again take over government - thus, having a great influence in the manner votes were cast (such views were shared in personal conversations with the author).

Action by the government against those perceived to be aligned towards the previous government and who were critical of the regime, by removing them from jobs or being persecuted by being subjected to long court trials after being charged with crimes (see Bhim 2011), further deterred some people from contesting the elections. The two former prime ministers, Laisenia Qarase (Tokalau, 2013) and Mahendra Chaudhry (Chand, 2014a) intending to contest the elections, were charged and convicted on 12-month sentences and unable to contest the elections, as the new criteria under the 2014 Electoral Decree does not allow people to contest if they have a conviction of 12 or more months in the eight years prior to elections.

The 1987, 2000 and 2006 coups in Fiji not only ousted legitimately elected MPs, they also deprived them of a source of livelihood. Some ousted MPs had difficulty finding employment and migrated overseas to work. The 2006 coup also resulted in MPs losing their sources of livelihood. Former FLP MP Lekh Ram Vayeshnoi, who was also the post-2006 coup Minister for Local Government until August 2008, moved to New Zealand in 2011 and was ordered by the Lautoka High Court not to sell his assets or withdraw savings, as he had failed to repay a $\$ 50,000$ debt to Bhavani Jewellers (Chand, 2011). A former SDL (Soqosoqo Duavata ni Lewenivanua party) Minister for Women and Culture, Adi Asenaca Caucau, left Fiji after being ousted in the 2006 coup, and was living and working in the United States when she hit the headlines in 2008 after being charged with domestic violence (Fijilive, 2008) - the charges were dismissed the following month. Former Minister Kenneth Zinck, who claims to have been tortured three times at the army barracks and questioned several times by soldiers at his home, fled to Australia in September 2011 and filed for a protection visa (Callick, 2011). Fiji residents had difficulty expressing political views following the start of media censorship after the abrogation of the 1997 Constitution in April 2009 and felt scared about job security. The risk of another coup was high as a way out for coup-makers had been provided by the immunity for the 2006 coup-makers entrenched in the new 2013 Fiji constitution. Parties found it difficult to recruit candidates (see Bhim, cited in Dovirerata, 2014). Certainly, the message to the cream of Fiji's society was that it was not worth investing in a political career due to the possibility of losing everything after military takeovers. The future for politicians in Fiji appeared bleak.

The 2014 Electoral Decree was published on 28 March 2014, less than six months before elections day. In 2006, Fiji's House of Representatives comprised 71 seats. The number of seats in Parliament has been reduced to 50 under the 2013 Fiji Constitution 
POLITICAL JOURNALISM IN THE ASIA-PACIFIC

Table 1: Fiji 2014 General Election candidates
\begin{tabular}{|l|c|c|c|}
\hline $\begin{array}{l}\text { Political party/ } \\
\text { Independent }\end{array}$ & $\begin{array}{c}\text { Number of } \\
\text { nominations received }\end{array}$ & Number rejected & Number approved \\
\hline NFP & 50 & 1 & 49 \\
\hline FLP & 42 & 5 & 37 \\
\hline SODELPA & $50(1$ withdrawal $)$ & 1 & 48 \\
\hline FUFP & 4 & 1 & 3 \\
\hline One Fiji & 14 & 1 & 13 \\
\hline PDP & 50 & 4 & 46 \\
\hline FijiFirst & 50 & Nil & 50 \\
\hline Independent & 2 & Nil & 2 \\
\hline Total & $262(1$ withdrawal $)$ & 13 & 248 \\
\hline
\end{tabular}

Source: 2014 General Elections - Final Report by Supervisor of Elections, Fiji Elections Office p. 24

(Section 54 (1), p. 31). Despite the challenges, in addition to FijiFirst, the NFP, PDP and SODELPA nominated 50 candidates. The Fiji Elections Office rejected four nominations from PDP, one from NFP, five from FLP, one from SODELPA and one candidate each from the One Fiji and FUFP parties (see Table 1).

After withdrawal of one candidate from SODELPA, FijiFirst was the only party fielding 50 candidates. There was a last-minute rush to recruit candidates in the two months before elections. Most people did not have an equal opportunity to become a candidate as workplaces require people to resign to stand in elections. If they lose the elections, they would not be able to return to work or, if removed after elections through a coup, they could face financial woes and hardships. Furthermore, party offices were not in operation for more than six years and had little or no activity. Parties regenerated after the announcement of elections and there was not enough time given for parties to fully activate for elections. Apart from FLP, there were new leaders for all parties. A brief look at the candidates' profiles reveals that the majority of the persons who stood for elections were those working in independent fields, were self-employed, could return to their former jobs if they lost the elections, or who could sustain being unemployed.

IPU criteria Section 3 Clause (2) states: 'Everyone has a right to join, or together with others has a right to establish, a political party or organisation for the purpose of competing in an election.' Apart from the perception of insecurity which deterred some citizens from joining political parties, there were no other impediments to realisation of this clause.

However, the major violations occurred for Clauses (3) and (4) of Section 3, which are: Clause (3): Everyone individually and together with others has the right:

- To express political opinions without interference;

114 PACIFIC JOURNALISM REVIEW 21(1) 2015 
- To seek, receive and impart information and to make an informed choice;

- To move freely within the country in order to campaign for elections;

- To campaign on an equal basis with other political parties, including the party forming the existing government.

Before the campaigning period, a strengthened Public Order Decree, imposed after the cessation of the Public Emergency Regulations in place since the 2006 coup, as well as the enforcement of the Media Industry Development Decree 2010 (known as the Media Decree) saw the prosecution of previous Fiji Times editor Netani Rika and current editor Fred Wesley. The country's pioneering TV station Fiji One, which began broadcasting in Fiji in 1993, was subjected to legal action and scrutiny by the government and their operations restricted through issuance of temporary six-month licences (Narayan, 19 June 2014). Prominent human rights activist Rev Akuila Yabaki of the CSO Citizens' Constitutional Forum (CCF) was given a three-month sentence suspended for one year and CCF fined FJ $\$ 20,000$ for an article published in April 2012 in their newsletter, Tutaka, criticising the independence of the Fiji judiciary (Naleba, 2013). CSOs were not allowed to hold panel discussions in the lead-up to the elections. Such discussions were normally held at the University of the South Pacific (USP) during any major political event in Fiji. However, they had to be cancelled and postponed till after the elections. A clause (Section 115) in the Electoral Decree required all training relating to elections and all printed material to be approved by the Fiji Elections Office. As such, a discussion paper by CCF on free and fair elections was ordered to be recalled and removed from their website, and they had to postpone their public conversation events on Separation of Powers, Bill of Rights and Transition Process (Pratap, 2014). However, as the campaign commenced in full strength, people expressed their views more freely.

\section{The campaigning period-Media and MIDA}

IPU Section 3. Clause (4) states: 'Every candidate for election and every political party shall have an equal opportunity of access to the media, particularly the mass communications media, in order to put forward their political views'.

This criterion was not fulfilled during the campaigning period for the September 2014 Fiji Election mainly due to the extensive and favourable reporting of the FijiFirst political party by the state-owned Fiji Sun daily newspaper and the state-owned daily radio and television broadcaster, Fiji Broadcasting Corporation (FBC), whose biased reporting possibly resulted in FijiFirst winning the election and the other parties losing. Headed by Riyaz Sayed-Khaiyum, the brother of Attorney-General (AG) and general-secretary of the FijiFirst party, Aiyaz Sayed-Khaiyum, the FBC ran talkback shows in the lead-up to the elections. While representatives from other political parties appeared once or twice on the talkback shows where they were grilled by their hosts, Bainimarama and Khaiyum were repeatedly interviewed, both in English and the vernacular languages. Prominent political party leaders Ro Teimumu Kepa (SODELPA), Felix Anthony (PDP), Professor 
POLITICAL JOURNALISM IN THE ASIA-PACIFIC

Biman Prasad (NFP) and Mahendra Chaudhry (FLP) were questioned in an abrupt and abrasive manner with a lot of interjections by interviewers and were asked questions which automatically portrayed them and their parties in a negative light by making them appear guilty and incompetent, in FBC TV's 4theRecord and Aaina (Hindi-language) programme (episodes 138-143, August-September 2014).

By comparison, the interviewers were sympathetic and respectful when interviewing Bainimarama in 4theRecord programme and the i-Taukei language programmes, $\mathrm{Na}$ Vakakeli and Bati Ni Tanoa. Similarly, AG Khaiyum was interviewed in a sympathetic and respectful manner on 4theRecord and Aaina programmes and both Bainimarama and Khaiyum were allowed to speak at length to answer questions without undue interjections. While interviewing candidates, host for 4theRecord Edwin Nand and hosts for Aaina, Veena Bhatnagar and Shammi Lochan, gave their political stance that they did not think there was anything wrong with everyone in Fiji being called a 'Fijian'. In research ethics and journalism this is unethical questioning, as it is a leading question which is likely to make the guest respond in a manner that suits the agenda of the interviewer. Ethical behaviour of journalists and researchers requires that open questions be asked and the interviewers' own personal beliefs and feelings should not be shown. The above behaviour by the three hosts infringes on the Media Code of Ethics and Practice of the 2010 Media Decree, which states media organisations 'shall not allow personal or family interest to influence them in their professional duties' and 'shall show fairness at all times, and impartiality and balance in any item or programme.... when presenting news which deals with political matters, current affairs and controversial questions'.

By comparison, the Fiji TV programmes, Outside the Box and Close-Up, had fairer treatment of FijiFirst and other parties. In Outside the Box programme, four candidates from different political parties were interviewed each weekday and given an opportunity to discuss their views. Similarly, unlike the 4theRecord programme host, Close-Up host Stanley Simpson asked critical questions of AG Khaiyum on the promises in the FijiFirst manifesto, why it was not released earlier, and questions posed by other political parties about FijiFirst's manifesto, such as the possibility of high costs for promised free goods, including free milk and juice for school children, and whether that would lead to an increase in Fiji's debt levels. Simpson used the same line of questioning as for other parties and Khaiyum had to defend the manifesto.

This difference in attitudes of interviewers can be seen when viewing Ro Teimumu's interview on 4theRecord (Ep 40, 2014) where she was not allowed to speak freely due to continuous interjections which portrayed her in a negative light. However, in the interview on Straight Talk (14 September 2014) by Communications Fiji Limited's Vijay Narayan (livestreamed on the internet), Ro Teimumu was confident and was able to explain and justify the party's mandate and her vision for a Fiji where there will be no more coups and an end to the coup culture. Bainimarama, on the other hand, appeared flustered on 
the Straight Talk programme and stumbled in answering questions many times, although the interviewer treated him with extreme courtesy. Similarly, Bainimarama was not as confident in answering questions in the (14 September 2014) Close Up interview by Stanley Simpson where he could not strongly justify that the SDL government was rife with corruption, due to very few prosecutions on corruption charges of SDL-related officials. The different behaviour by the TV hosts led to the SODELPA party questioning the format of the 4theRecord programme, which was cited as one of the reasons Ro Teimumu declined to appear a second time on the programme (Carnegie, 2014).

Reviewing stories covered by the two daily newspapers shows coverage of all political parties by The Fiji Times from August to September 2014. By comparison, the Fiji Sun gave biased extensive coverage to the FijiFirst party and gave negative and a small amount of coverage to other parties. Similarly, FijiVillage covered all political parties in its news and radio programmes. By comparison, the FBC gave extensive and preferential coverage to the FijiFirst party and negative or little coverage to other parties.

The preferential treatment of FijiFirst by the Fiji Sun and FBC was in stark contradiction with the Media Decree which requires 'fairness' and 'balance'. The decree established the Media Industry Development Authority (MIDA) and its Chairman, Ashwin Raj, announced on 26 March 2014 that they would set up an independent unit to monitor the way the media report on political campaigns, and ensure that newspapers and radio and television stations do not show bias in the way they report on politics (ABC News, 2014). A week before the elections, Raj appealed to Fijians to refrain from using the media (including social media) to incite violence through the use of inflammatory language to intimidate voters following allegations of death threats against two journalists (PMC, 2014). Raj stated that: 'The media must also remain independent, give equal access to all political actors, must not be seen as aiding and abetting the agenda of one political party over others...' (Ibid.). Raj, did not however, mention that the inflammatory reporting may have been done by the FBC and Fiji Sun, and he has so far not taken any action against their biased reporting towards the FijiFirst party. This has led to questions on MIDA's effectiveness and impartiality and if there is any need for such a body.

IPU Clause (5) highlights the rights of candidates to security with respect to their lives and property; and Clause (7) emphasises that any restrictions should be consistent with the state's obligations under international law and should not violate the principle of non-discrimination. There appears to be no violation of these two criteria.

IPU Clause (6) states: 'Every individual and every political party has the right to the protection of the law and to a remedy for violation of political and electoral rights.' Clause (8): 'Every individual or political party whose candidature, party or campaign rights are denied or restricted shall be entitled to appeal to a jurisdiction competent to review such decisions and to correct errors promptly and effectively.' There appears to be no violation of these two criteria as individuals and political parties had the right to appeal decisions made by the Fiji Elections Office through court action. 
POLITICAL JOURNALISM IN THE ASIA-PACIFIC

\section{Section 4. The rights and responsibilities of states}

The major violations during the 2014 Fiji Elections occurred for six clauses under IPU criteria Section 4. The Rights and Responsibilities of States. Clause (1) says that states should ... ensure the separation of party and state; and Clause (2) says that states should take the necessary steps to ensure the establishment of a neutral, impartial or balanced mechanism for the management of elections.

Numerous calls were made by political parties and CSOs for a caretaker government to be appointed so that there could be separation of powers of party and the state. However, PM Bainimarama and his cabinet members - most of whom were contesting the elections - did not resign and continued to work as ministers, as well as campaign for elections at the same time. An Electoral Commission (EC) was created, chaired by Chen Bunn Young, with four independent members: University of the South Pacific's Professor Vijay Naidu; electoral commentator Father David Arms; former academic and playwright Larry Thomas; and social/community worker Alisi Daurewa. Young made a good start to the elections process by taking the initiative to invite CSOs and political parties to meetings at the Fiji Elections Office (FEO), where provisions of the Electoral Decree were explained, and Section 115 discussed which restricts foreign aid-funded NGOs from being involved in electoral-related activities and requires them to write to seek permission for voter education from the EC (Marau, 2014). This was a welcome move by the Commission which displayed a commitment to transparency. The lead displayed by the EC chair was followed by Supervisor of Elections Mohammed Saneem, who held regular press conferences after those initial briefing sessions. However, when the time came to draw the numbers for the candidates list, it was revealed that the Supervisor of Elections had a higher authority than the EC, as the EC recommendations to allow two nominees to contest were not upheld by the Supervisor. The court upheld the Supervisor's decision in an appeal filed by the EC, where Young argued that the Supervisor of Elections was bound by the Commission to follow its directive (Loga, 2014b). This revealed that the independent EC did not have powers of enforcement, whereas the FEO-a body made-up largely of former civil servants - had powers of enforcement.

The FEO went ahead with drawing numbers of candidates without the presence of the EC (Chand, 2014b) further proving that the EC held no real authority. Since the ruling of the court case, the 'independent' commission took a back stage and the whole election exercise was managed by the FEO which was largely comprised of civil servants - a body that is not regarded as independent and impartial of the incumbent Government.

There was a major violation of Clause (3): 'In time of elections, the state and its organs should therefore ensure: That parties and candidates are free to communicate their views to the electorate, and that they enjoy equality of access to state and public-service media; That the necessary steps are taken to guarantee non-partisan coverage in State and public-service media.'

118 PACIFIC JOURNALISM REVIEW 21(1) 2015 
The extensive and preferential coverage of the FijiFirst party and the incumbent government status quo by the Fiji Sun and FBC TV led to a perception that these two state-owned media were partisan and biased towards FijiFirst. No steps were taken by the incumbent government to make them independent.

Clause (4) states: 'In order that elections shall be fair, States should take the necessary measures to ensure that parties and candidates enjoy reasonable opportunities to present their electoral platform.' By failing to provide clear dates to political parties on when campaigns would be allowed to start, reasonable time was not given for them to prepare. Under the new Electoral Decree, all candidates were to be allocated a three-digit number for the elections. The draw of numbers took place on Saturday, 23 August 2014-less than one month before the elections. Pre-polling commenced after two weeks which means other parties only had two weeks for media advertising. While FijiFirst started extensive advertising well before this date, other political parties with limited budgets largely commenced media advertising after the draw of numbers. Television advertising is expensive and only the FijiFirst party extensively advertised on television for more than a month prior to elections. Parties focussed on advertising their leading candidates as the new electoral system had no demarcation of boundaries and constituencies-candidates had no constituencies and had to regard the whole country as their constituency, thus depriving them of a focused area to campaign. The new electoral system known as the open list proportional representation voting system (Hayward-Jones, 2014), favoured leading candidates and large parties - smaller parties and independents were wiped out because under Section 104 (3) of the Electoral Decree, any votes of parties or individuals amounting to less than 5 percent of total votes were disregarded. The system favoured the FijiFirst party, as their leading candidates had been in power for eight years and were well-known in Fiji. It was unfair to the other political parties who had been denied freedom of expression in the media for the past eight years and unfair to other candidates as it is difficult or impossible for most candidates to campaign in the whole of the country due to lack of resources.

Clause (7) says: 'States should take all necessary and appropriate measures to ensure the transparency of the entire electoral process including, for example, through the presence of party agents and duly accredited observers.' The Fiji government allowed a Multi-National Observer Group (MOG) comprising more than 90 observers to observe the 2014 Elections. However, a CSO domestic election observer group, which had applied much earlier on 18 June 2014 to the AG's office for accreditation, was not allowed to officially observe the elections as the AG felt the MOG was sufficient for observation (Sauvakacolo, 2014).

Clause (9) requires states to ensure that violations of human rights and complaints relating to the electoral process are determined promptly by an independent and impartial authority. A few political parties had appealed against the rejection of some of their nominated candidates. All court actions taken by political party candidates resulted in the 
POLITICAL JOURNALISM IN THE ASIA-PACIFIC

decisions favouring the FEO. The EC had decided in favour of two candidates rejected by the FEO. However, the FEO did not abide by the decisions of the EC and upheld its own approved list. In the court action mentioned earlier taken by the EC, the court upheld the FEO's decision. Coincidentally, these decisions favoured the FijiFirst party and were against the other parties, raising serious questions about the independence and transparency of these institutions.

\section{Transparency and accountability}

The principles of electoral integrity from the International Institute for Democracy and Electoral Assistance (IDEA), the ACE (Administration and Cost of Elections) Project, and other international bodies, emphasise the need for transparency and accountability (Ace Project, 2012) from the incumbent government. Such transparency needs to be exercised not only during the elections but also during preparation of legislation relating to elections. No consultations were held with stakeholders in the preparation of the Political Parties Decree 2012 and the Electoral Decree 2014, and draft decrees were not available to the public for comment and scrutiny before promulgation. Chief Justice Anthony Gates, as Acting President, amended the Electoral Decree on 31 July 2014 to decrease Fiji residence requirements for candidates to 18 months, without any consultation or notice (Turagaiviu, 2014). Protests by leaders of political parties fell on deaf ears. While other political parties announced their manifestos well before elections, the FijiFirst manifesto was launched on 5 September by Bainimarama, giving them enough time to scrutinise the other manifestos to ensure they were offering more free goods and services to entice other party's supporters. PM Bainimarama launched their manifesto after opening a new $\$ 844,000$ market extension in Nadi (Vafo'ou, 2014) thus again violating the international criteria that there must be separation of the party and the state. This was a non-transparent move by a party that claims to champion transparency, as they should have released their manifesto at the same time as the other parties.

The public were informed that a one-day election would be held; however, almost two weeks of pre-polling occurred before 17 September. The Voter Instruction Booklet had the number, name and picture of each candidate, but there were no political party names or symbols. This encouraged voting for the leaders of parties as voters would remember which parties the leaders belonged to. Party agents had difficulty monitoring the vote counting process as they tended to know few of their party representatives. A voter could vote for any of the 248 candidates at any polling station, and it was impossible for party agents to have information on the correct political party of all the 248 candidates to monitor their performance. The new electoral system allows leading candidates to redistribute their votes. Candidates with less than 1000 votes from FijiFirst became assistant ministers as the 202,459 votes received by Bainimarama (FEO, 2014) were redistributed to them, whereas several candidates from other parties with over 1000 votes did not get a seat in Parliament (Table 2).

120 PACIFIC JOURNALISM REVIEW 21(1) 2015 
POLITICAL JOURNALISM IN THE ASIA-PACIFIC

Table 2: Fiji 2014 Genera
\begin{tabular}{|l|c|c|c|}
\hline Name & Votection final results summary & $\%$ of total votes & Seats \\
\hline FijiFirst & 293714 & $59.2 \%$ & 32 \\
\hline Social Democratic Liberal Party & 139857 & $28.2 \%$ & 15 \\
\hline National Federation Party & 27066 & $5.5 \%$ & 3 \\
\hline People's Democratic Party & 15864 & $3.2 \%$ & 0 \\
\hline Fiji Labour Party & 11670 & $2.4 \%$ & 0 \\
\hline One Fiji Party & 5839 & $1.2 \%$ & 0 \\
\hline Fiji United Freedom Party & 1072 & $0.2 \%$ & 0 \\
\hline Independent - Roshika Deo & 1055 & $0.2 \%$ & 0 \\
\hline Independent - Umesh Chand & 226 & $0.0 \%$ & 0 \\
\hline
\end{tabular}

Source: 2014 General Elections - Final Report by Supervisor of Elections, Fiji Elections Office p. 22

\section{Concluding remarks}

While the conduct of the 17 September 2014 polling activities and counting of results could be deemed 'free and fair', the limitation of certain freedoms under restrictive laws and media bias did not allow all parties and candidates a fair chance to compete on a level platform with the FijiFirst Party. The preferential and biased coverage by the Fiji Sun and FBC, combined with a lack of separation of the government-based FijiFirst party and the two state-funded daily media, the perceived threat of instability if another party won, and the lack of independent statutory bodies with powers for oversight,led to a majority victory by the FijiFirst party and stifled the aspirations of many political party candidates who may have achieved success under a fairer system.

The 2014 Fiji Elections largely satisfied IPU's Criteria 2. Voting and Elections Rights, which deals with the polling and counting processes. However, while the polling and counting processes can be deemed 'free and fair', the 2014 Fiji Elections failed to satisfy the other three IPU criteria which are: 1. Free and Fair Elections; 2. Candidature Party and Campaign Rights and Responsibilities; and 4. Rights and Responsibilities of States. If international observers were not following all four criteria, then Fiji's 2014 elections could not be deemed 'free and fair'.

The post-coup regime's media censorship was effective and bore fruit. The censorship of critical news, accompanied by flooding of the media with extensive positive publicity of government activities from a large sophisticated government media team, was successful in winning the poorly informed masses. Fiji's grassroots have again showed increasing naivety by considering the government as being highly endowed and doing them favour by giving 'gifts'. This shows a lack of understanding by voters that they could have more ownership and control of government and could have demanded 


\section{POLITICAL JOURNALISM IN THE ASIA-PACIFIC}

more and better goods and services in a more timely manner under a freer democratic system with a free media and judiciary. Fiji's democracy remains young and fledgling with hopes for a better future.

\section{References}

4TheRecord, Ep 36. (2014, July 21). Peceli Rokotuivuna, Edwin Nand, Nemani Delaibatiki interview FijiFirst leader and PM Bainimarama, published on YouTube. Fiji Broadcasting Corporation. Retrieved on November 4, 2014, from www.youtube.com/watch?v=eJ7SeBypTxk

4TheRecord, Ep 40. (2014, August 17). Edwin Nand, Joshua Tuwere interview SODELPA leader Ro Teimumu Kepa, published on YouTube. Fiji Broadcasting Corporation. Retrieved on March 24, 2015, from www.youtube.com/watch? $\mathrm{v}=\mathrm{uQNF} 7$ tpufDM

Aaina, Ep 136. (2014, July 23). Veena Bhatnagar interviews NFP Leader Prof Biman Prasad, published on U-tube on July 23 2014. Fiji Broadcasting Corporation. Retrieved on 31 October 2014, from http://www.youtube.com/watch?v=d5oc2qKKNJM

Aaina, Ep 138. (2014, August 6). Veena Bhatnagar interviews Prof Biman Prasad and Aiyaz Khaiyum, published on YouTube. Fiji Broadcasting Corporation. Retrieved on October 31, 2014, from www.youtube.com/watch? v=v8rb1 twQwb8

Aaina, Ep 140. (2014, August 20). Shammi Lochan interviews FLP Leader Mahendra Chaudhry, published on YouTube. Retrieved on October 31, 2014, from www.youtube.com/watch?v=eISBkxpUfU

Aaina, Ep 141. (2014, August 27). Shammi Lochan interviews PDP Leader Felix Anthony, published on YouTube. Fiji Broadcasting Corporation. Retrieved on October 31, 2014, from www. youtube.com/watch? $\mathrm{v}=\mathrm{gXID} 86 \mathrm{TA} 7 \mathrm{MA}$

Aaina, Ep 142. (2014, September 3). Shammi Lochan interviews NFP's Attar Singh and Anshu Singh and Fiji First's Aiyaz Khaiyum and Veena Bhatnagar, published on YouTube. Retrieved on October 31, 2014, from www.youtube.com/watch?v=nefEXBv-0PE

Aaina, Ep 143. (2014, September 10). Shammi Lochan interviews FijiFirst's General Secretary and AG Aiyaz Khaiyum on their manifesto, published on YouTube. Fiji Broadcasting Corporation. Retrieved on October 31, 2014, from www.youtube.com/watch? $=w$ wDB9ENeJ3Tw

Aaina, Ep 144 - Shammi Lochan interviews MIDA Chairman Ashwin Raj, published on U-tube on September 24 2014. Fiji Broadcasting Corporation. Retrieved on 31 October 2014, from http://www.youtube.com/watch?v=1ZrY_br2E-8

ABC News. (2014, March 27). Fiji to set up media monitor ahead of election. ABC News. Retrieved on November 13, 2014, from www.abc.net.au/news/2014-03-26/fiji-media-monitor/5347638

ACE Project. (2012). Electoral Integrity. Guiding principles of electoral integrity [3rd Edition]. ACE Project. Retrieved on October 20, 2014, from http://aceproject.org/ace-en/topics/ei/ei20

Baledrokadroka, J. (2012). The unintended consequences of Fiji's international peacekeeping. Security Challenges, 8(4), pp. 105-116.

BBC News. (2009, September 1). Fiji suspended from Commonwealth. British Broadcasting Corporation. Retrieved on November 3, 2014, from http://news.bbc.co.uk/2/hi/8231717.stm

Bhim, M. (2011). Stifling opposition: An analysis of the approach of the Fiji government after the 2006 coup. SSGM Discussion Paper, Australian National University. Retrieved on March 11, 2013, from http://ips.cap.anu.edu.au/ssgm/papers/discussion_papers/2011_06_bhim.pdf

Callick, R. (2011, September 21). Former Fiji Minister Kenneth Zinck seeks protection in Australia. The Australian. Retrieved on March 23, 2015, from www.theaustralian.com.au/

122 PACIFIC JOURNALISM REVIEW 21(1) 2015 
national-affairs/immigration/former-labour-minister-escapes-after-hectic-car-chase/storyfn9hm1gu-1226142174514?nk=9b8b78cb8c9115c07f6db96c1 eee 8173

Carnegie, T. (2014, September 9). SODELPA replies in controversy over cancelled TV debate. Pacific Scoop [Pacific Media Centre]. Retrieved on November 12, 2014, from http://pacific. scoop.co.nz/2014/09/sodelpa-replies-in-controversy-over-debate-cancellation/

Centre for Human Rights. (1994). Human rights and elections-A handbook on the legal, technical and human rights aspects of elections. United Nations, New York and Geneva.

Chand, S. (2011, July 30). Judge puts freeze on ex-MP's house. Fiji Times Online. Retrieved on November 12, 2014, from www.fijitimes.com/story.aspx?id=176412

Chand, S. (2014a, April 5). Chaudhry guilty. Fiji Times Online. Retrieved on March 23, 2015, from www.fijitimes.com/story.aspx?id=264718

Chand, S. (2014b, August 28). Electoral Commission boycotts number draw. Fiji Times Online. Retrieved on November 14, 2014, from http://elections.fijitimes.com.fj/Story/278643

Close Up. (2014, August 10). Stanley Simpson interviews FLP Leader Mahendra Chaudhry, published on YouTube. Fiji Television. Retrieved on October 31, 2014, from www.youtube. $\mathrm{com} /$ watch? $=2 \mathrm{HuN7itS7YE}$

Close Up. (2014, August 17). Stanley Simpson interviews NFP's Tupou Draunidalo, published on YouTube. Fiji Television. Retrieved on October 31, 2014, from www.youtube.com/ watch? $=$ =uaduUN42rIQ

Close Up. (2014, August 24). Stanley Simpson interviews SODELPA Leader Ro Teimumu Kepa, published on YouTube. Fiji Television. Retrieved on October 31, 2014, from www.youtube. com/watch? $\mathrm{v}=$ wJQj9UlilBk

Close Up. (2014, August 31). Stanley Simpson interviews Leader of One Fiji Party Filimoni Vosarogo, published on YouTube. Fiji Television. Retrieved on October 31, 2014, from www. youtube.com/watch? $\mathrm{v}=\mathrm{xHQ} 3 \mathrm{~F} 7 \mathrm{bbxb0}$

Close Up. (2014, September 8). Stanley Simpson interviews FijiFirst General Secretary Aiyaz Sayed-Khaiyum, published on YouTube. Fiji Television. Retrieved on October 31, 2014, from www.youtube.com/watch?v=dyMW2I-5Yz4

Close Up. (2014, September 7). Stanley Simpson interviews PDP Leader Felix Anthony, published on YouTube on 7 September 2014. Retrieved on 31 October 2014, from http://www.youtube. $\mathrm{com} /$ watch? $\mathrm{v}=$ MEgmIAAnsR4

Close Up. (2014, September 14). Stanley Simpson interviews FijiFirst's Voreqe Bainimarama, published on YouTube. Retrieved on October 31, 2014, from www.youtube.com/ watch? $\mathrm{v}=2 \mathrm{v} 0 \mathrm{XrLfKEmY}$

Commonwealth Heads of Government. (1995, November 12). Millbrook Commonwealth Action Programme on the Harare Declaration. Commonwealth Secretariat, London. Retrieved on November 3, 2014, from http://thecommonwealth.org/sites/default/files/history-items/documents/millbrook\%20declaration.pdf

Constitution of the Republic of Fiji 2013. (2013, August 23). Available at www.electionsfiji.gov. fj/wp-content/uploads/2013/09/Constitution-of-the-Republic-of-Fiji-.pdf

Doviverata, R. (2013, August10). Calling on new actors. Fiji Sun Online. Retrieved on August 18, 2013, from www.fijisun.com.fj/2013/08/10/calling-on-new-actors/

Fijian Elections Office. (2014). Final Results for the 2014 General Elections. Fijian Elections Office. Retrieved on March 26, 2015, from http://fijione.tv/fiji-first-party-launch-manifesto/

Fijian Elections Office. (2014, October 22). 2014 General Election-Final Report by Supervisor of Elections. Fijian Elections Office. Retrieved on November 12, 2014, from www.electionsfiji. gov.fj/wp-content/uploads/2014/11/Final-Report-by-Supervisor-of-Elections.pdf 


\section{POLITICAL JOURNALISM IN THE ASIA-PACIFIC}

Fijilive. (2008, July 31). Govt awaits ex-SDL minister's passport. Fijilive. Retrieved on November 12, 2014, from http://fijilive.com/fijliive-print-story.Fijilive?7249.Fijilive

Fiji Sun. (2013, August 22). Constitution of the Republic of Fiji 2013. Fiji Sun Online. Retrieved on November 10, 2014, from http://fijisun.com.fj/2013/08/23/constitution-of-the-republicof-fiji-2013/

Fijian Elections Office. (2013). 2013 Constitution. Fijian Elections Office. Retrieved on November 10, 2014, from www.electionsfiji.gov.fj/2013-constitution/

Government of Fiji. (2010, June 25). Media Industry Development Decree 2010 (Decree No. 29 of 2010). Government Printer, Suva.

Government of Fiji. (2013, January 15). Political Parties (Registration, Conduct, Funding and Disclosures) Decree 2013 (Decree No. 4 of 2013). Government Printer, Suva.

Government of Fiji. (2014, 28 March). Electoral Decree 2014. (Decree No. 11 of 2014). Government Printer, Suva.

Hayward-Jones, J. (2014, January 21). Fiji: An election in 2014 and Bainimarama will stand. The Interpreter - Lowy Institute for International Policy. Retrieved on March 25, 2015, from www.lowyinterpreter.org/post/2014/01/21/Fiji-An-election-in-2014-and-Bainimarama-willstand.aspx

Inter-Parliamentary Council. (1994, March 26). Declaration on Criteria for Free and Fair Elections. Inter-Parliamentary Union, Geneva. Retrieved on October 21, 2014, from www.ipu.org/ cnl-e/154-free.htm

Loga, M. (2014a, July 31). Electoral Commission criticised on silence over vandalism attacks. Fiji One Television. Retrieved on March 24, 2015, from http://fijione.tv/electoral-commissioncriticised-on-silence-over-vandalism-attacks/

Loga, M. (2014b, August 23. Fiji's Electoral Commission takes Supervisor of Elections to Court. Fiji Television Limited. Retrieved on November 14, 2014, from http://fijione.tv/electoralcommission-takes-supervisor-of-elections-to-court/

Marau, M. (2014, April 4). Fiji Electoral Commission to seek independent legal advice on Electoral Decree. Fiji Television Limited. Retrieved on March 24, 2015, from http://fijione.tv/ fiji-electoral-commission-to-seek-independent-legal-advice-on-electoral-decree/

Naleba, M. (2013, August 9). Yabaki gets suspended sentence, CCF cops $\$ 20,000$ fine. The Fiji Times Online. Retrieved on March 24, 2015, from www.fijitimes.com/story.aspx?id=242211

Narayan, V. (2014, June 19). Fiji TV given another six month extension. Fijivillage.com. Retrieved on June 20, 2014, from http://fijivillage.com/news/Fiji-TV-given-another-six-monthextension-s25rk9/

Narayan, V., \& Turaga, S. (2014, September 18). Multinational Observer Group says this was a credible election. Fijivillage.com. Retrieved on September 22, 2014, from http://fijivillage. $\mathrm{com} /$ news/Multinational-Observer-Group-says-this-was-a-credible-election-5k9sr2/

Pacific Media Watch. (2014, September 10). 8955 Fiji: Don't use social media to incite violence, pleads MIDA chair. Pacific Media Centre, AUT University. Retrieved on November 13, 2014, from www.pmc.aut.ac.nz/pacific-media-watch/fiji-dont-use-social-media-incite-violencepleads-mida-chair-8955

Pratap, R. (2014, August 7). FICAC searches CCF office for documents. Fiji Broadcasting Corporation. Retrieved on March 24, 2015, from www.fbc.com.fj/fiji/21977/ficac-searchesccf-office-for-documents-

Radio Australia. (2014, March 29). Fiji set for September 17 poll. ABC Radio Australia. Retrieved on November 11, 2014, from www.radioaustralia.net.au/international/2014-03-28/fiji-set-forseptember-17-poll/1287006

124 PACIFIC JOURNALISM REVIEW 21(1) 2015 
Radio New Zealand International (RNZI). (2012, March 5). Bainimarama does not rule out standing for Fiji election in 2014. RNZI. Retrieved on March 23, 2015, from www.radionz.co.nz/international/pacific-news/203004/bainimarama-does-not-rule-out-standing-for-fiji-election-in-2014

Sauvakacolo, S. (2014, August 30). Request Rejected. The Fiji Times Online. Retrieved on September 5, 2014, from www.fijitimes.com/story.aspx?ref=archive\&id=278750

Stolz, E. (2014, September 11). FijiFirst leader reassured public. Fiji Broadcasting Corporation. Retrieved on September 11, 2014, from www.fbc.com.fj/fiji/22896/fijifirst-leader-reassured-public

Straight Talk. (2014, September 14). Vijay Narayan interviews FijiFirst's Voreqe Bainimarama and SODELPA's Ro Teimumu Kepa, streamed live. Published on YouTube by FijiVillage. Retrieved on October 31, 2014, from www.youtube.com/watch?v=niuJ96IFRhU

Susu, A. (2014, September 6). Leave military alone, replies commander. Fiji Sun Online. Retrieved on September 8, 2014, from http://fijisun.com.fj/2014/09/06/leave-military-alone-repliescommander/

Swami, N. (2014, September 19). Election was free and fair: Electoral Commission. The Fiji Times Online. Retrieved on September 20, 2014, from www.fijitimes.com/story.aspx?id=280725

Sydney Morning Herald (SMH). (2007, May 4). Bainimarama won't contest next Fiji Poll. The Sydney Morning Herald. Retrieved on March 23, 2015, from www.smh.com.au/news/World/ Bainimarama-wont-contest-next-Fiji-poll/2007/05/04/1177788377305.html

Tokalau, T. (2013, April 4). Qarase back home. The Fiji Times Online. Retrieved on March 23, 2015, from http://www.fijitimes.com/story.aspx?id=230055

Torching of Fiji's Constitutional papers 'despicable', says PM Tuilaepa. (2013, January 10). Talamua Online, Samoa. Retrieved on January 22, 2013, from www.talamua.com/torchingof-constitutional-papers-despicable-says-pm-tuilaepa/

Turagaiviu, E. (2014, August 4). Changes in the Electoral Decree. Fiji Broadcasting Corporation. Retrieved on March 25, 2015, from www.fbc.com.fj/fiji/21871/changes-in-the-electoral-decree

Vafo'ou, R. (2014, September 5). FijiFirst Party launch manifesto. Fiji Television Limited. Retrieved on March 25, 2015, from http://fijione.tv/fiji-first-party-launch-manifesto/

Vukailagi, D. (2014, March 4). Colonel Mosese Tikoitoga is new military commander. Fiji Television Limited. Retrieved on November 4, 2014, from http://fijione.tv/colonel-mosesetikoitoga-is-new-military-commander/

United Nations. (1948, December 12). Universal Declaration of Human Rights.

Mosmi Bhim is a lecturer in ethics and governance at the Fiji National University in Suva and a former journalist. She iwas part of the second batch of graduates of the University of the South Pacific Regional Journalism Programme which was revived by French aid in 1994. She is a previous contributor to Pacific Journalism Review. This article is based on analysis and observation of the 2014 Elections process in Fiji. The views expressed in this article are her own and not of the FNU.

mosmi_bhim@hotmail.com 